\title{
Job-Sorting Assignment to Assess Cream Liqueur Brand Image
}

\author{
Adriana Gámbaro ${ }^{1, *}$, Carmen Ivankovich ${ }^{2}$, Antonella Roascio ${ }^{1}$, Miguel Amarillo ${ }^{1}$, \\ Marcelo Miraballes ${ }^{1}$ and Yorleny Araya-Quesada ${ }^{3}$
}

1 Sección Evaluación Sensorial, Departamento de Ciencia y Tecnología de Alimentos, Facultad de Química, Universidad de la República, General Flores 2124, CP 11800, Montevideo, Uruguay; aroascio@fq.edu.uy (A.R.); amarillom@fq.edu.uy (M.A.); mmiraballes@fq.edu.uy (M.M.)

2 Centro Nacional de Ciencia y Tecnología de Alimentos (CITA), Universidad de Costa Rica, CP 11501-2060, San José, Costa Rica; carmen.ivankovich@ucr.ac.cr

3 Escuela de Tecnología de Alimentos, Universidad de Costa Rica, CP 11501-2060, San José, Costa Rica; yorleny.araya@ucr.ac.cr

* Correspondence: agambaro@fq.edu.uy; Tel.: +598-2924-8003

Academic Editor: Miranda Mirosa

Received: 28 September 2016; Accepted: 3 February 2017; Published: 10 February 2017

\begin{abstract}
Projective techniques rely on a stimulus to elicit from respondents projections of their beliefs onto other people or objects, thus reflecting their own perceptions, feelings and motivations. In this work, the job-sorting technique, in combination with Aaker's personality scale, was applied to the study of cream liqueur brand image in Uruguay and Costa Rica. Eight jobs with different levels of intellectual complexity, salary and physical demands were selected. In each of the two countries, three (two imported and one locally made) liqueurs were presented to 90 consumers with similar socio-demographic characteristics. Respondents were told to select the job, profession or occupation (JPO) that best fitted each brand. After JPO selection, respondents were asked to select from a list of 88 personality traits all the words that they considered applicable to each JPO selected. The JPOs associated with the different brands showed no similarity between Uruguayan and Costa Rican respondents, but the personality traits associated with the two imported brands were similar in both countries, supporting the use of JPOs as metaphors in the study of brand images. The brand image of locally made liqueurs was associated with traits that differed clearly from those of the imported brands. These results provide relevant information for the design of marketing strategies.
\end{abstract}

Keywords: cream liqueur; projective techniques; consumer behavior; brand image; job sorting

\section{Introduction}

Product brands and company names, in addition to their legal aspects, carry the connotations that consumers confer on them based on their experience with the product or company [1]. Associations, perceptions, valuations, symbols and mental constructs held or made by consumers can be conveniently relied on by brand names to differentiate themselves from their competitors. It has also been noted that the relationship between a brand and its consumers meets certain needs of the consumers, such as gaining social status or a sense of belonging in reference to a particular group [2]. Fournier proposed that different brands carry some meaning in relation to each other and add meaning to consumers' lives by talking on roles as partners or friends [3]. To a consumer, a product or service is more than the sum of its attributes; it also carries an affective component and a symbolic meaning [4,5], both of which have an impact on a consumer's sense of social status and self-esteem.

The consumer's image of a brand goes beyond the real product, into the symbolic realm in the consumer's mind, where the consumer finds significance based on his or her personal experience, 
values, beliefs, attitudes and aspirations [6]. Any personal interpretation involves implicit unconscious knowledge associated with previous ideas, attitudes, self-esteem and stereotypes [7].

Tools are therefore needed to enable a deeper understanding of consumer needs and responses [8] as well as their implications. Metaphor-based techniques allow the respondent to explore the object of study by means of analogies, through which the subjective information that he or she requires is provided. According to Knight, "A metaphor is a way of understanding, expressing and experiencing one kind of things in terms of another" [9]. The author also mentions that the true beauty of the metaphor is the way in which every person interprets and lives the metaphor itself. Projective techniques or tests allow free interpretation and response to an ambiguous stimulus; they seek to understand the motives, feelings, beliefs, attitudes and deep-seated reasons that lead to particular response choices on a specific topic [10-12]. In market research, projective tests are used to explore the respondent's perception and comprehension of the object of study in his or her very own words [10]. Animation sets can be used to identify the underlying perception of a brand or product. In the personification technique, respondents project a personality onto a stimulus that could be a brand, product, image, or similar.

By definition, projective techniques involve the use of a loosely-structured stimulus that allows respondents to project their beliefs and thoughts, which may be unconscious. Projecting responses onto something or someone detached from the subject that provides information allows respondents to believe that the information is attributable to someone or something else, rather than originating from themselves $[13,14]$. Whereas projective techniques were created and applied in the field of psychology, they have also been used in consumer behavior and market research studies in order to understand consumers' needs with regard to an object of study [15]. They complement quantitative data that can be used to shed light onto the source of consumers' perceptions, feelings and motives, eliciting information from deeper and unconscious levels that can be accessed through spontaneous or emotional response $[10,16]$. Information that is not available when conventional, explicit and direct methods are used can thus be revealed [7].

Throughout history, anthropomorphism has been a way of communicating with the non-material realm, attributing human features to animals, objects or natural phenomena. It provides a means of understanding consumer perceptions of products or services $[1,3]$. In turn, the use of psychological language, in which nouns and adjectives describe human personalities as they develop and maintain interpersonal relationships, contributes elements of social behavior and descriptors of personality traits to the study of consumers [17]. Projective techniques can humanize or personalize brands, treating them as companions or friends. Researchers have classified or subdivided projective techniques into five categories: association, completion, building, sorting and expression techniques $[11-13,18]$. Association techniques include personality association techniques, used to research the type and profile of potential products or service users [8].

Caprara et al. found that personality can be used as a suitable metaphor to address the perception of brand image [17]. One of the most widely used tools to measure brand personality is Aaker's personality scale $[19,20]$. The scale was obtained from a list of 309 non-redundant traits reduced to 42 final traits, grouped into five dimensions: sincerity, excitement, competence, sophistication and ruggedness. In later studies, Aaker's personality traits were used in an associative manner, for example, "select three personality traits for each job" [11] or were presented using a Likert scale. Aaker's scale has been subject to some revisions [21,22] and concern has been expressed over its generalization [23]. The most comprehensive analysis was reported by Caprara, et al. [17], who asserted that brand personality adjectives have a relational context and sense, i.e., different meanings can transition between dimensions, depending on the brand. Likewise, other researchers, for example, George and Charles [24], believe that the construction of a certain brand's personality does not provide grounds for the analysis of all brands, mainly because many brands do not depend on large communication strategies and cannot be characterized by specific values. Despite this criticism, Aaker's scale is still the most widely used tool for the assessment of brand personality $[20,25]$. Another association technique, 
job-sorting, is based on associations with job types. It is a projective technique using jobs, professions or occupations (JPO) as metaphors [11,18].

In this paper, the job-sorting technique, in combination with Aaker's personality scale was applied to three cream liqueurs to assess the brand personalities associated with them, in Uruguay and Costa Rica. Unlike the methodology used by Anouk [11] and Upadhyaya and Mohindra [18], the full Aaker's list of brand personality traits was used, rather than one reduced to five dimensions (sincerity, excitement, competence, sophistication and ruggedness), enabling a greater richness of metaphors.

\section{Materials and Methods}

\subsection{Construction of Measuring Instrument-Occupation Selection for Job-Sorting Technique}

In the job-sorting technique, cards illustrating different types of occupation are used. Participants are asked to connect jobs with the brands studied. According to Anouk, et al. [11], the jobs must represent a combination of high and low levels of the following characteristics: intellectual complexity, salary level and physical demands, resulting in eight possible combinations (Table 1). For example, one of the jobs must represent the following combination: low salary, low intellectual complexity and high physical load.

Table 1. Jobs selected for the job-sorting task.

\begin{tabular}{cccc}
\hline Job & Intellectual Complexity & Salary & Physical Load \\
\hline Security guard & Low & Low & Low \\
Government employee & Low & High & Low \\
Gardener & Low & Low & High \\
International football player & Low & High & High \\
Primary school teacher & High & Low & Low \\
Software programmer & High & High & Low \\
Physical education teacher & High & Low & High \\
Agricultural engineer & High & High & High \\
\hline
\end{tabular}

As it was inappropriate to use the job categories used for job sorting tasks by authors in other countries [18], a preliminary study was conducted in order to determine the jobs that best represented each combination. Twenty university students from Uruguay and 20 from Costa Rica took part in the preliminary survey. Participants were presented with combinations of high and low levels of the three characteristics and were asked to name jobs that reflected each particular combination. Using these data, eight jobs that were described in the same manner in both countries were selected. To verify the job selection, a second survey was conducted using another 20 university students from each country, who were presented with the names of the selected jobs, on the one hand, and the combinations of characteristics, on the other hand, and were asked to match the jobs with their characteristics. In this way, the relationship between the jobs and their characteristics was confirmed by all respondents in both countries. These results are shown in Table 1.

For each job, an image illustrating the occupation was shown on a laminated card also bearing the job name. A cartoon dog was used to ensure participants based their responses only on the job characteristics (and not, for example, on the gender or facial expression of a particular character shown on the cards). Simple drawings were made in black and white on each card.

\subsection{Brand Personality Trait Selection}

All 42 items of Aaker's brand personality list were used [19,20], together with two additional items incorporated by Ferrandi, et al. (charismatic and superficial) [26], which were considered appropriate for personifying the image of cream liqueurs. Items were translated into Spanish according to the parallel back-translation procedure [27]. Because personality characteristics are bipolar (i.e., someone can be either very friendly, or not at all friendly), the antonym of each personality trait was also provided, making up a list of 88 items (Table 2). This is in line with Anouk, et al. [11] and Geuens, et al. [25], so that participants could check all that apply from the whole list, including opposite terms. 
Table 2. Brand personality traits used in this study in English/Spanish.

\begin{tabular}{|c|c|c|c|}
\hline Personality Trait & Opposite Trait & Personality Trait & Opposite Trait \\
\hline Up-to-date/Actualizado & Out-of-date/Desactualizado & Imaginative/Imaginativo & Unimaginative/Sin imaginación \\
\hline Cheerful/Alegre & Sad/Triste & Independent/Independiente & Dependent/Dependiente \\
\hline Friendly/Amigable & Unfriendly/No amigable & Intelligent/Inteligente & Dumb/Tonto \\
\hline Cool/Atractivo & Uncool/Cobarde & Young/Joven & Old/Viejo \\
\hline Daring/Audaz & Unnoticed/Desapercibido & Leader/Líder & Follower/Seguidor \\
\hline Real/Auténtico & Unreal/No auténtico & Masculine/Masculino & Effeminate/Afeminado \\
\hline Upper-class/Clase alta & Lower-class/Clase baja & Western/Occidental & Eastern/Oriental \\
\hline Confident/Confiado & Unconfident/Desconfiado & Family-oriented/Orientado a la familia & Not family-oriented/No orientado a la familia \\
\hline Contemporary/Contemporaneo & Old-fashioned/Anticuado & Small-town/Provinciano & City dweller/Citadino \\
\hline Corporate/Corporativo & Individualistic/Individualista & Down-to-earth/Realista & Dreamer/Soñador \\
\hline Trendy/De moda & Archaic/Antiguo & Wholesome/Saludable & Unwholesome/Enfermizo \\
\hline Outdoorsy/De puertas para afuera & Indoorsy/De puertas para adentro & Secure/Seguro & Insecure/Inseguro \\
\hline Reliable/Digno de confianza & Unreliable/Poco digno de confianza & Sentimental/Sentimental & Hardened/Duro \\
\hline Tough/Tenaz & Weak/Flojo & Sincere/Sincero & Hypocritical/Hipócrita \\
\hline Exciting/Emocionante & Unexciting/No emocionante & Technical/Técnico & Unskilled/Inexperto \\
\hline Charming/Encantador & Unappealing/Antipático & Hard-working/Trabajador & Lazy/Vago \\
\hline Spirited/Entusiasta & Dull/Apagado & Smooth/Afable & Rude/Descortés \\
\hline Successful/Exitoso & Unsuccessful/Fracasado & Unique/Único & Commonplace/Corriente \\
\hline Feminine/Femenino & Manly/Macho & Rugged/Violento & Calm/Tranquilo \\
\hline Glamorous/Glamoroso & Shabby/Andrajoso & Original/Original & Fake/Falso \\
\hline Good-looking/Guapo & Ugly/Feo & Charismatic/Carismático & Bland/Soso \\
\hline Honest/Honesto & Dishonest/Deshonesto & Superficial/Superficial & Profound/Profundo \\
\hline
\end{tabular}




\subsection{Consumer Sample}

The study was conducted in Montevideo, Uruguay's capital, and in San José, the capital of Costa Rica. With the aim of comparing the applicability of the method in the two countries, consumer samples were so selected that their socio-demographic profiles were as similar as possible. Thus, for each country, the consumer sample comprised 90 university students from a medium or high socioeconomic background, aged between 18 and 30 (average of 24.9, SD = 3.8 and 22.2, SD = 2.5 in Uruguay and Costa Rica, respectively) who occasionally or regularly consumed cream liqueurs, $66.7 \%$ and $60.2 \%$ of whom in Uruguay and Costa Rica, respectively, were women. Participants were recruited on the campuses of Universidad de la República (Uruguay) and Universidad de Costa Rica (Costa Rica).

\subsection{Products}

For the analysis of the applicability of the job-sorting task to cream liqueur brands, two imported brands widely sold in both countries (brands A and B) and one locally-made brand mild caramel-flavored cream liqueur in Uruguay (brand U) and coffee-flavored cream liqueur in Costa Rica (brand C) were selected.

\subsection{Procedure}

The procedure reported by Anouk [11] was adapted as follows. In one single session, consumers were presented with the cards bearing images of the eight jobs and were allowed some time to become familiar with the images and the jobs. They were then presented with bottles of the three liqueurs simultaneously and again were allowed some time to become familiar with them. Respondents who reported not being acquainted with one particular brand were told to imagine what the product might be like from what could be inferred from its bottle. They were later told to select the job, profession or occupation (JPO) that best fitted each of the brands, with the possibility of repeating the selected JPOs.

After JPO selection, the bottles were withdrawn and respondents were asked to select from the list of 88 personality traits (Table 2) all the words that they considered applicable to each of the selected JPOs.

\subsection{Data Analysis}

Frequency of mention (expressed as percentage of respondents) was determined and the data were analyzed using Cochran's $Q$ test. Finally, correspondence analysis was conducted to obtain a spatial representation reflecting the relationship between the brands studied and the traits selected by participants in each of the two countries. All statistical analyses were carried out with XL-Stat 2013 software (Addinsoft, New York, NY, USA).

\section{Results}

The frequency of mention of each JPO is shown in relation to each brand in Figures 1 and 2 for Uruguay and Costa Rica, respectively.

Figures 1 and 2 show that the jobs associated with the different brands differed between the two countries. In Uruguay, brand A was associated mainly with agricultural engineers, linked with the countryside and the open air; whereas in Costa Rica it was associated with the position of government employee, reflecting an image of safety, comfort and bureaucracy. In Uruguay, brand B was associated with software programmers and international football players, that is, technological skills and international popularity; whereas in Costa Rica brand B was linked with government employees, implying an image of comfort and privilege. The Uruguayan brand (brand $U$ ) was associated mainly with school teachers, reflecting popularity and family orientation, with little tendency to be modern; whereas the Costa Rican brand (brand C), associated with agricultural engineers, was seen as more competitive than brand $\mathrm{U}$. 


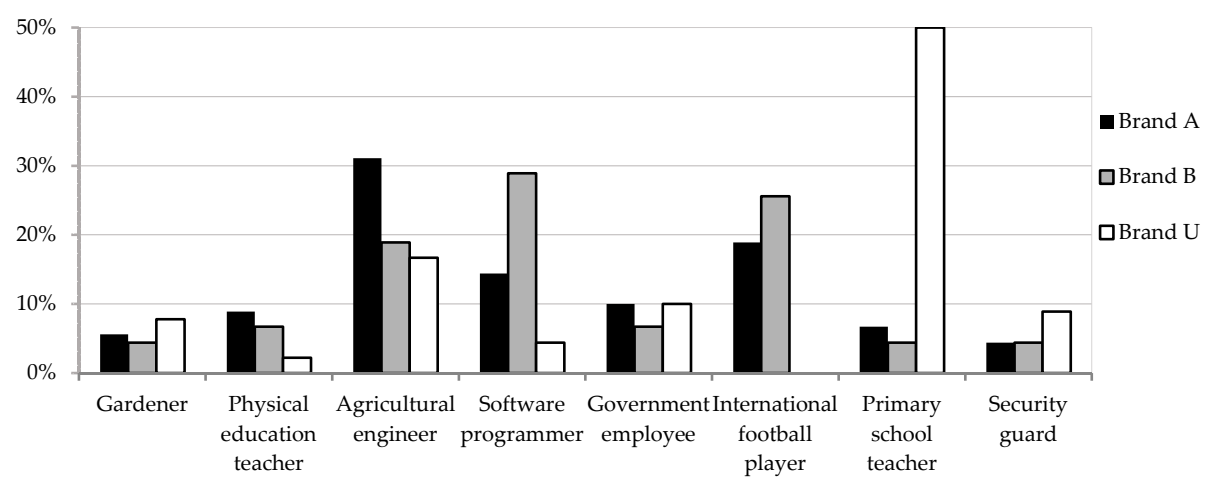

Figure 1. Frequency of mention of each JPO according to brand: Uruguay.

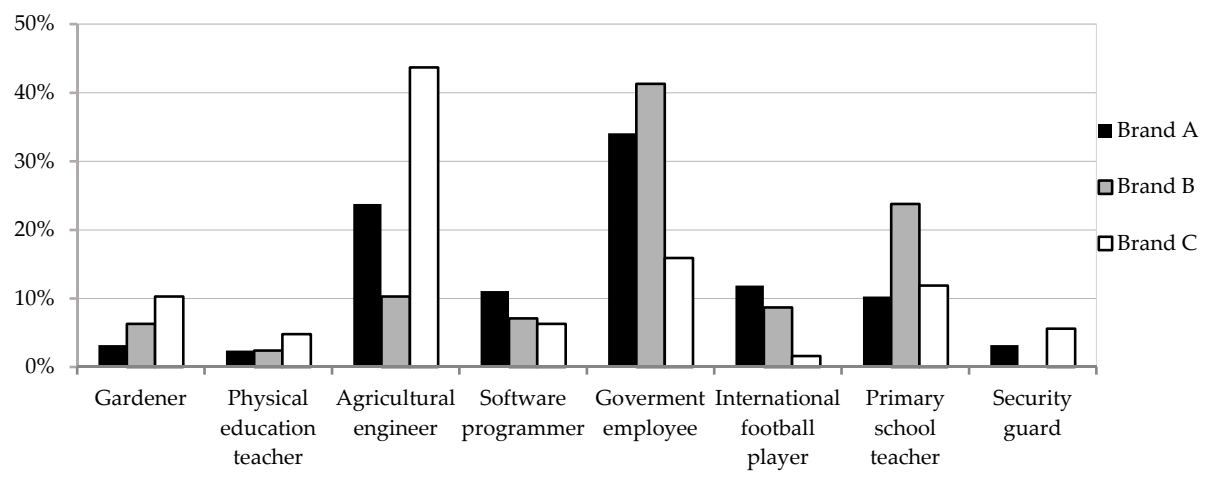

Figure 2. Frequency of mention of each JPO according to brand: Costa Rica.

Of the 88 personality traits presented to respondents to describe the jobs selected for each brand, those which were mentioned by less than $10 \%$ of respondents in reference to all of the brands ( 22 items in Uruguay and seven in Costa Rica) were removed. Tables 3 and 4 show the percentage of respondents that assigned each of the remaining personality traits to each brand.

Table 3. Frequency of mention for each personality trait according to brand in Uruguay. The association to personality item was done indirectly via the intermediate selection of a JPO.

\begin{tabular}{cccc}
\hline Personality Item $^{*}$ & \multicolumn{3}{c}{ Frequency of Mention } \\
\cline { 2 - 4 } & Brand A & Brand B & Brand U \\
\hline Down-to-earth $^{\text {ns }}$ & 31.1 & 32.2 & 30.0 \\
Dreamer $^{\text {ns }}$ & 38.9 & 34.4 & 26.7 \\
Family oriented $^{* * *}$ & 28.9 & 23.3 & 55.6 \\
Not family-oriented $^{\text {ns }}$ & 8.9 & 14.4 & 5.6 \\
Small-town $^{\text {ns }}$ & 20.0 & 15.6 & 20.0 \\
City dweller $^{* *}$ & 25.6 & 30.0 & 11.1 \\
Honest $^{* * *}$ & 25.6 & 31.1 & 60.0 \\
Sincere $^{\text {ns }}$ & 17.8 & 16.7 & 25.6 \\
Original $^{\text {ns }}$ & 20.0 & 18.9 & 26.7 \\
Wholesome $^{\text {ns }}$ & 40.0 & 37.8 & 32.2 \\
Real $^{\text {ns }}$ & 27.8 & 18.9 & 20.0 \\
Cheerful $^{\text {ns }}$ & 30.0 & 31.1 & 20.0 \\
Sentimental $^{\text {ns }}$ & 16.7 & 13.3 & 17.8 \\
Hardened $^{\text {ns }}$ & 12.2 & 20.0 & 58.9 \\
Friendly $^{* *}$ & 43.3 & 34.4 & 6.7 \\
Unfriendly $^{\text {ns }}$ & 7.8 & 11.1 &
\end{tabular}


Table 3. Cont.

\begin{tabular}{|c|c|c|c|}
\hline \multirow{2}{*}{ Personality Item } & \multicolumn{3}{|c|}{ Frequency of Mention } \\
\hline & Brand A & Brand B & Brand U \\
\hline Good-looking ** & 14.4 & 14.4 & 2.2 \\
\hline Ugly $\mathrm{ns}^{\mathrm{O}}$ & 11.1 & 6.7 & 6.7 \\
\hline Calm ${ }^{\text {ns }}$ & 44.4 & 45.6 & 52.2 \\
\hline Rugged ${ }^{\text {ns }}$ & 3.3 & 12.2 & 3.3 \\
\hline Western $^{\text {ns }}$ & 16.7 & 11.1 & 11.1 \\
\hline Charismatic $^{\text {ns }}$ & 27.8 & 32.2 & 40.0 \\
\hline Unnoticeable $^{\text {ns }}$ & 15.6 & 20.0 & 11.1 \\
\hline Daring $^{\mathrm{ns}}$ & 37.8 & 37.8 & 26.7 \\
\hline Trendy $* * *$ & 23.3 & 22.2 & 4.4 \\
\hline Old-fashioned ${ }^{\text {ns }}$ & 8.9 & 11.1 & 16.7 \\
\hline Exciting $^{\text {ns }}$ & 17.8 & 20.0 & 14.4 \\
\hline Unexciting $^{\mathrm{ns}}$ & 3.3 & 12.2 & 12.2 \\
\hline Spirited ${ }^{\text {ns }}$ & 35.6 & 23.3 & 31.1 \\
\hline Dull ${ }^{\mathrm{ns}}$ & 8.9 & 14.4 & 8.9 \\
\hline Cool * & 14.4 & 14.4 & 3.3 \\
\hline Young ** & 33.3 & 48.9 & 24.4 \\
\hline Old * & 20.0 & 12.2 & 27.8 \\
\hline Imaginative $^{\mathrm{ns}}$ & 37.8 & 41.1 & 46.7 \\
\hline Unique $^{\text {ns }}$ & 14.4 & 12.2 & 5.6 \\
\hline Commonplace ${ }^{\mathrm{ns}}$ & 12.2 & 10.0 & 16.7 \\
\hline Up-to-date * & 50.0 & 41.1 & 30.0 \\
\hline Independent $^{\text {ns }}$ & 37.8 & 35.6 & 25.6 \\
\hline Contemporary ${ }^{\mathrm{ns}}$ & 23.3 & 25.6 & 16.7 \\
\hline Archaic ${ }^{n s}$ & 8.9 & 7.8 & 15.6 \\
\hline Charming $^{\text {ns }}$ & 14.4 & 11.1 & 11.1 \\
\hline Outdoorsy $^{\text {ns }}$ & 15.6 & 14.4 & 11.1 \\
\hline Indoorsy ${ }^{\mathrm{ns}}$ & 17.8 & 18.9 & 13.3 \\
\hline Tough $^{\text {ns }}$ & 24.4 & 28.9 & 28.9 \\
\hline Superficial $* *$ & 13.3 & 23.3 & 6.7 \\
\hline Profound ${ }^{\text {ns }}$ & 11.1 & 13.3 & 16.7 \\
\hline Reliable ${ }^{* * *}$ & 26.7 & 24.4 & 60.0 \\
\hline Hard-working * & 46.7 & 52.2 & 63.3 \\
\hline Lazy $^{\text {ns }}$ & 6.7 & 10.0 & 2.2 \\
\hline Secure ns & 41.1 & 36.7 & 41.1 \\
\hline Intelligent ${ }^{\mathrm{ns}}$ & 43.3 & 42.2 & 41.1 \\
\hline Technical * & 44.4 & 43.3 & 27.8 \\
\hline Corporate $^{\mathrm{ns}}$ & 7.8 & 14.4 & 12.2 \\
\hline Individualistic ** & 25.6 & 23.3 & 8.9 \\
\hline Successful ** & 27.8 & 33.3 & 12.2 \\
\hline Leader ${ }^{\text {ns }}$ & 25.6 & 17.8 & 22.2 \\
\hline Follower $^{\text {ns }}$ & 11.1 & 10.0 & 8.9 \\
\hline Confident $^{\text {ns }}$ & 28.9 & 30.0 & 24.4 \\
\hline Upper-class ${ }^{* *}$ & 25.6 & 23.3 & 6.7 \\
\hline Lower-class ${ }^{\text {ns }}$ & 11.1 & 7.8 & 17.8 \\
\hline Glamorous ** & 8.9 & 11.1 & 1.1 \\
\hline Feminine $* * *$ & 10.0 & 5.6 & 26.7 \\
\hline Masculine ${ }^{* *}$ & 61.1 & 65.6 & 44.4 \\
\hline Manly $^{\text {ns }}$ & 14.4 & 14.4 & 10.0 \\
\hline Rude $^{\text {ns }}$ & 20.0 & 25.6 & 16.7 \\
\hline Smooth ${ }^{\text {ns }}$ & 4.4 & 4.4 & 12.2 \\
\hline
\end{tabular}

* Significant difference $(p \leq 0.05) ; * *$ Very significant difference $(p \leq 0.01) ; * * *$ Highly significant difference $(p \leq 0.0001) ;{ }^{\text {ns }}$ Non-significant differences $(p>0.05)$, according to Cochran's test. 
Table 4. Frequency of mention for each personality trait according to cream liqueur brand in Costa Rica. The association to personality item was done indirectly via the intermediate selection of a JPO.

\begin{tabular}{|c|c|c|c|}
\hline \multirow{2}{*}{ Personality Item } & \multicolumn{3}{|c|}{ Frequency of Mention } \\
\hline & Brand A & Brand B & Brand C \\
\hline Down-to-earth ${ }^{\text {ns }}$ & 32.2 & 28.9 & 45.6 \\
\hline Dreamer $^{\mathrm{ns}}$ & 41.1 & 34.4 & 32.2 \\
\hline Family oriented ${ }^{\mathrm{ns}}$ & 34.4 & 44.4 & 46.7 \\
\hline Not family-oriented ${ }^{\text {ns }}$ & 18.9 & 20.0 & 15.6 \\
\hline Small-town ** & 22.2 & 24.4 & 44.4 \\
\hline City dweller ** & 47.8 & 46.7 & 24.4 \\
\hline Honest $^{\mathrm{ns}}$ & 40.0 & 35.6 & 50.0 \\
\hline Dishonest $^{\mathrm{ns}}$ & 28.9 & 33.3 & 20.0 \\
\hline Sincere $^{\text {ns }}$ & 35.6 & 26.7 & 43.3 \\
\hline Hypocritical ** & 26.7 & 35.6 & 13.3 \\
\hline Original $^{\mathrm{ns}}$ & 36.7 & 30.0 & 38.9 \\
\hline Fake * & 22.2 & 30.0 & 14.4 \\
\hline Wholesome ${ }^{\text {ns }}$ & 54.4 & 48.9 & 56.7 \\
\hline Real $^{\text {ns }}$ & 34.4 & 25.6 & 37.8 \\
\hline Unreal * & 23.3 & 28.9 & 14.4 \\
\hline Cheerful $^{\text {ns }}$ & 54.4 & 51.1 & 55.6 \\
\hline Sentimental ${ }^{\text {ns }}$ & 13.3 & 17.8 & 13.3 \\
\hline Hardened $^{\text {ns }}$ & 33.3 & 28.9 & 35.6 \\
\hline Friendly ${ }^{\mathrm{ns}}$ & 47.8 & 57.8 & 55.6 \\
\hline Unfriendly $\mathrm{ns}^{\mathrm{n}}$ & 14.4 & 13.3 & 10.0 \\
\hline Good-looking $^{\text {ns }}$ & 17.8 & 14.4 & 10.0 \\
\hline Ugly ${ }^{\mathrm{ns}}$ & 16.7 & 20.0 & 20.0 \\
\hline Calm ${ }^{\text {ns }}$ & 43.3 & 48.9 & 54.4 \\
\hline Rugged ${ }^{\text {ns }}$ & 8.9 & 11.1 & 3.3 \\
\hline Western $^{\text {ns }}$ & 33.3 & 35.6 & 34.4 \\
\hline Charismatic $^{\text {ns }}$ & 57.8 & 51.1 & 46.7 \\
\hline Unnoticeable $^{\text {ns }}$ & 13.3 & 14.4 & 13.3 \\
\hline Daring $^{\mathrm{ns}}$ & 48.9 & 45.6 & 46.7 \\
\hline Trendy $* * *$ & 25.6 & 30.0 & 7.8 \\
\hline Old-fashioned ${ }^{\mathrm{ns}}$ & 14.4 & 15.6 & 24.4 \\
\hline Exciting $^{\mathrm{ns}}$ & 24.4 & 16.7 & 18.9 \\
\hline Unexciting ${ }^{n s}$ & 16.7 & 26.7 & 24.4 \\
\hline Spirited $^{\mathrm{ns}}$ & 40.0 & 45.6 & 53.3 \\
\hline Dull ${ }^{\text {ns }}$ & 10.0 & 11.1 & 10.0 \\
\hline Cool $^{\text {ns }}$ & 14.4 & 16.7 & 15.6 \\
\hline Bland $^{\mathrm{ns}}$ & 16.7 & 14.4 & 16.7 \\
\hline Young $^{\text {ns }}$ & 34.4 & 32.2 & 32.2 \\
\hline $\mathrm{Old}^{\mathrm{ns}}$ & 30.0 & 33.3 & 35.6 \\
\hline Imaginative $^{\mathrm{ns}}$ & 40.0 & 41.1 & 45.6 \\
\hline Unimaginative $^{\mathrm{ns}}$ & 11.1 & 15.6 & 11.1 \\
\hline Unique $^{\text {ns }}$ & 15.6 & 16.7 & 15.6 \\
\hline Commonplace ${ }^{\text {ns }}$ & 18.9 & 23.3 & 18.9 \\
\hline Up-to-date ${ }^{n s}$ & 52.2 & 47.8 & 45.6 \\
\hline Out-of-date ${ }^{\text {ns }}$ & 8.9 & 13.3 & 16.7 \\
\hline Independent * & 47.8 & 32.2 & 37.8 \\
\hline Dependent ${ }^{n s}$ & 11.1 & 16.7 & 12.2 \\
\hline Contemporary ${ }^{* *}$ & 36.7 & 35.6 & 20.0 \\
\hline Archaic* & 7.8 & 11.1 & 21.1 \\
\hline Charming $^{\text {ns }}$ & 17.8 & 21.1 & 21.1 \\
\hline Unappealing $^{\text {ns }}$ & 13.3 & 15.6 & 11.1 \\
\hline Outdoorsy * & 30.0 & 22.2 & 14.4 \\
\hline Indoorsy ${ }^{\mathrm{ns}}$ & 11.1 & 12.2 & 12.2 \\
\hline Tough ns & 45.6 & 35.6 & 45.6 \\
\hline Weak $^{\text {ns }}$ & 10.0 & 17.8 & 13.3 \\
\hline Superficial ${ }^{* *}$ & 33.3 & 37.8 & 15.6 \\
\hline Profound ${ }^{\mathrm{ns}}$ & 18.9 & 8.9 & 18.9 \\
\hline Reliable $^{\text {ns }}$ & 30.0 & 25.6 & 40.0 \\
\hline
\end{tabular}


Table 4. Cont.

\begin{tabular}{|c|c|c|c|}
\hline \multirow{2}{*}{ Personality Item } & \multicolumn{3}{|c|}{ Frequency of Mention } \\
\hline & Brand A & Brand B & Brand C \\
\hline Unreliable * & 28.9 & 35.6 & 17.8 \\
\hline Hard-working ** & 48.9 & 41.1 & 64.4 \\
\hline $\operatorname{Lazy}^{\mathrm{ns}}$ & 22.2 & 30.0 & 18.9 \\
\hline Secure ns & 54,4 & 40.0 & 51.1 \\
\hline Insecure ${ }^{\text {ns }}$ & 6.7 & 6.7 & 12.2 \\
\hline Intelligent ${ }^{\mathrm{ns}}$ & 53.3 & 56.7 & 56.7 \\
\hline Dumb ns & 11.1 & 10.0 & 6.7 \\
\hline Technical ${ }^{\text {ns }}$ & 51.1 & 45.6 & 53.3 \\
\hline Corporate $^{\mathrm{ns}}$ & 24.4 & 17.8 & 13.3 \\
\hline Individualistic ns & 30.0 & 37.8 & 34.4 \\
\hline Successful ${ }^{\mathrm{ns}}$ & 50.0 & 44.4 & 40.0 \\
\hline Leader ${ }^{n s}$ & 43.3 & 47.8 & 37.8 \\
\hline Follower ${ }^{\text {ns }}$ & 15.6 & 21.1 & 20.0 \\
\hline Confident $^{\mathrm{ns}}$ & 33.3 & 30.0 & 28.9 \\
\hline Unconfident $^{\text {ns }}$ & 13.3 & 13.3 & 8.9 \\
\hline Upper-class ${ }^{* *}$ & 44.4 & 50.0 & 27.8 \\
\hline Lower-class $* * *$ & 10.0 & 24.4 & 33.3 \\
\hline Glamorous ** & 30.0 & 35.6 & 15.6 \\
\hline Shabby * & 13.3 & 5.6 & 18.9 \\
\hline Feminine $^{\text {ns }}$ & 11.1 & 22.2 & 13.3 \\
\hline Masculine * & 55.6 & 46.7 & 61.1 \\
\hline Manly ${ }^{\text {ns }}$ & 32.2 & 31.1 & 38.9 \\
\hline Rude * & 32.2 & 26.7 & 42.2 \\
\hline Smooth ${ }^{\text {ns }}$ & 12.2 & 17.8 & 11.1 \\
\hline
\end{tabular}

${ }^{*}$ Significant difference $(p \leq 0.05) ;{ }^{* *}$ Very significant difference $(p \leq 0.01) ;{ }^{* * *}$ Highly significant difference $(p \leq 0.0001) ;{ }^{\text {ns }}$ Non-significant differences $(p>0.05)$, according to Cochran's test.

In both Uruguay and in Costa Rica, the three brands elicited mentions of similar personality traits, which may be attributed to the generic image of 'cream' liqueurs. In both countries, cream liqueurs were associated with the personality traits dreamer, wholesome, cheerful, calm, imaginative, secure, intelligent, masculine and tough. In Uruguay, the three brands were associated with independent and hard-working personalities. In Costa Rica, all three brands were also associated with the traits family-oriented, honest, technical, up-to-date, individualistic, successful and friendly, in addition to either young or old. According to Cochran's test, significant differences $(p \leq 0.05)$ between the three brands were found for 20 and 19 personality traits in Uruguay and Costa Rica, respectively.

The brand image of the locally-made liqueurs (brand $U$ in Uruguay and brand C in Costa Rica) showed clearly different personality traits from those of the imported liqueurs. In Uruguay, brand $U$ was associated with a more family-oriented, honest, friendly, old, reliable, hard-working and feminine personality than that of the imported brands. In Costa Rica, brand $\mathrm{C}$ was associated with a small-town, archaic, hard-working, lower-class, masculine and rude personality.

The traits associated with the two imported brands (A and B) did not differ substantially between the two countries, where they were described as city-dwelling, trendy, superficial, upper-class and glamorous. In addition, compared with the locally-made brands, imported brands A and B were associated with a cooler, younger, more up-to-date, technical, individualistic, successful and masculine personality in Uruguay, and with a more hypocritical, fake, unreal, contemporary, outdoorsy and unreliable personality in Costa Rica.

Only one personality trait associated with the two imported brands differed significantly between Uruguay and Costa Rica, being associated with a younger personality and a more independent personality, respectively.

Correspondence analysis accounted for $100 \%$ of the variance in both countries, with Factor 1 accounting for most of the variability $(85.0 \%$ in Uruguay and $75.9 \%$ in Costa Rica). Factor 1 
clearly separated the two imported brands from the local brand, indicating the proximity of the imported brands, and the difference between them and the local brand, in the mind of consumers. In both countries, Factor 1 correlated negatively mainly with glamorous, upper-class, lazy, good-looking, trendy and superficial and positively with honest, sincere, old-fashioned, archaic, reliable and lower-class.

Despite several coincidences, differences between the two countries were reflected in some of the brand personality traits that showed the greatest correlation with Factor 1. In Uruguay (Figure 3), Factor 1 correlated positively with family-oriented, original, sentimental, friendly, unexciting, old, commonplace, smooth and feminine, and negatively with successful, individualistic, technical, unique, young, cool, unnoticed, rugged and not family-oriented. In contrast, in Costa Rica (Figure 4), Factor 1 correlated positively with small-town, real, out-of-date, profound, hard-working, unconfident, shabby and rude, and negatively with dishonest, hypocritical, fake, unreal, unfriendly, rugged, contemporary, unappealing, outdoorsy, unreliable, dumb, corporate, unconfident, feminine and smooth.

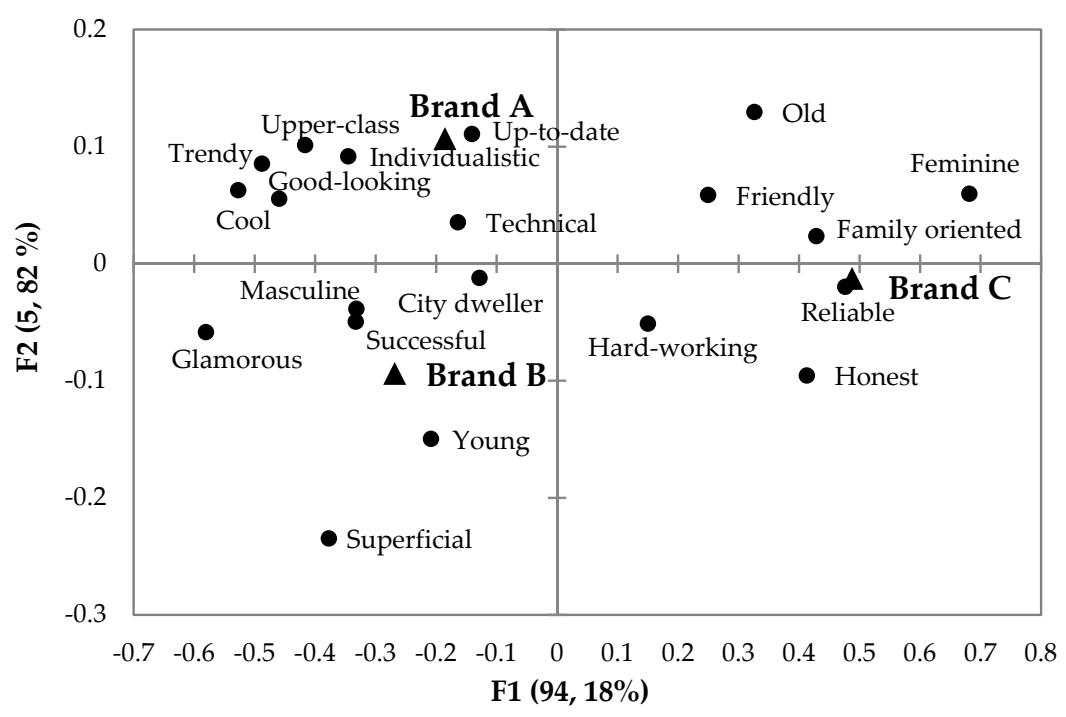

Figure 3. Factorial correspondence analysis of brand personality traits with significant difference according to Cochran's $Q$ test: Uruguay.

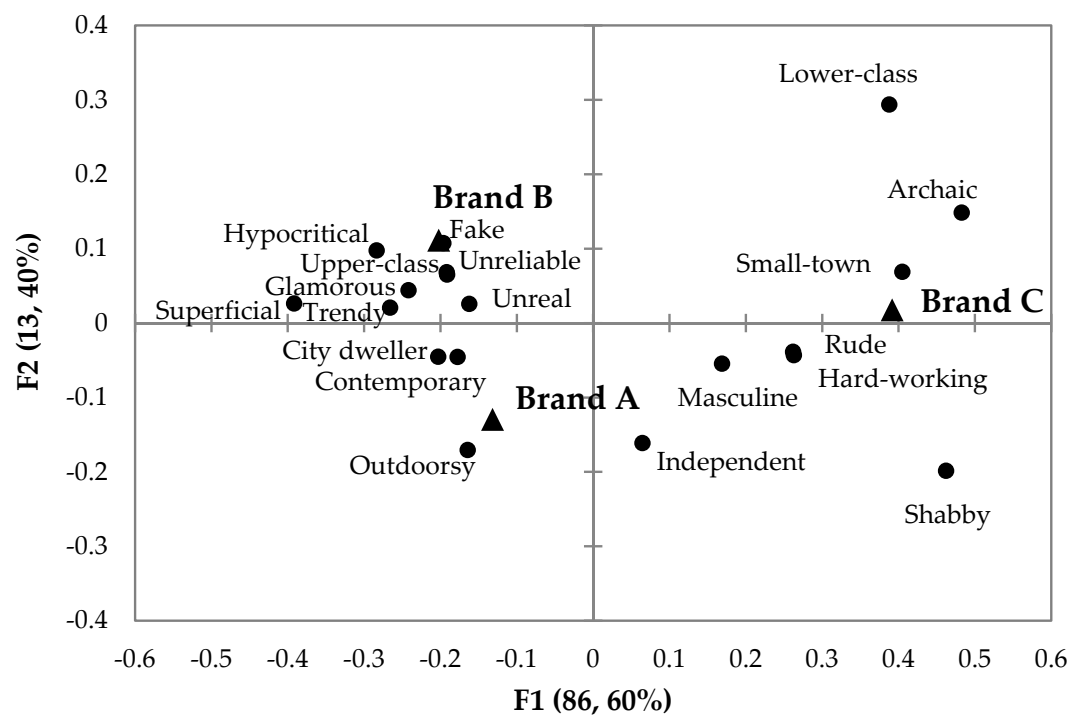

Figure 4. Factorial correspondence analysis of brand personality traits with significant difference according to Cochran's Q test: Costa Rica. 


\section{Discussion}

Most of the items that were not selected by at least $10 \%$ of consumers in relation to one or more of the brands had a negative connotation. The personality traits dishonest, hypocritical, fake, unwholesome*, unreal, sad*, Eastern*, uncool*, bland, unimaginative, out-of-date, dependent, unpleasant, weak, unreliable, insecure, dumb, unskilled*, unsuccessful ${ }^{*}$, unconfident, shabby and effeminate* were not included in the analysis of Uruguayan data; while those marked with an asterisk were not included in the Costa Rican data. It may be assumed that all these negative items were not associated with the generic image of 'cream' liqueurs.

The perception of the locally-made brands is influenced by the idea of what is "ours", national and local, associated with the archetype of what is known and familiar, favoring a sense of trust in the product and its acceptance. The fact these brands were perceived as old and archaic implies an opportunity for improving market position. The perception of a hard-working trait suggests an unglamorous image and seems suitable for middle-aged people with a more responsible world view. In Uruguay, the perception of a brand as feminine suggests a more sensitive and expansive, though less powerful image, compared with the masculine archetype or descriptor. In the case of brand $\mathrm{U}$, the above association may relate largely to the label design, which depicts a typical view of the Uruguayan countryside.

The imported brands were associated with a more glamorous and modern image that is up-to-date with technology and entertainment, active and trendy, evoking acceptance among equals and in the modern world. Mentions of superficiality relate to detachment from family, allowing new kinds of relationships, feelings and forms of entertainment, following socially accepted norms that are considered successful. The descriptor of masculinity is seen as synonymous with success, in a world where men are seen as having permission to behave in certain ways (e.g., being adventurous) without experiencing disapproval. These liqueurs are perceived as helping both men and women to achieve what the masculine archetype promises: strength, power, conquest, and license to act without being criticized.

Product decisions made by consumers are often linked not only to the product's characteristics or consumers' needs but also to symbolic and affective relations [28]. As Hussey and Duncombe established, a brand image is the combination of two dimensions: personality and identity [4]. The brand personality is understood as the internal features experienced by the subconscious brain. With the use of a metaphor, consumers do not concentrate on the motives that make them make a decision; because responses are unconscious they do not have to rationalize their opinions.

In this sense, imported brands appear to have demonstrated greater consumption potential than that of local brands. The latter, whether in Uruguay or Costa Rica, could benefit from a marketing strategy that confers a more appealing and powerful image on them, with a view to generating sufficient consumption potential to compete with the imported brands.

\section{Conclusions}

Although the jobs most often associated with each individual brand differed between Uruguay and Costa Rica, some brand personality traits were associated with imported cream liqueurs in both countries, supporting the appropriateness of using jobs as metaphors for the study of brand image. The use of the JPOs as a metaphor proved to be a good tool for the study of brand image and the identification of brand personality traits associated with different brands. Such information is relevant for decision making in the area of marketing strategy design.

These results are preliminary and should be considered as such. Future work should use larger consumer samples and should compare the results obtained using this technique with those obtained using other projective techniques. In future studies, the direct association of personality traits to the brand could be studied and compared to the personality traits selected with the use of a JPO as a metaphor. 
Author Contributions: A.G. and C.I. conceived and designed the experiments; A.R., M.M., M.A and Y.A. performed the experiments; A.G., C.I., A.R. and Y.A. analyzed the data; A.G. and C.I. wrote the paper.

Conflicts of Interest: The authors declare no conflict of interest.

\section{References}

1. Hudson, S.; Huang, L.; Roth, M.S.; Madden, T.J. The influence of social media interactions on consumer-brand relationships: A three-country study of brand perceptions and marketing behaviors. Int. J. Res. Mark. 2016, 33, 27-41. [CrossRef]

2. Budac, C.; Baltador, L. The Value of Brand Equity. Procedia Econ. Financ. 2013, 6, 444-448. [CrossRef]

3. Fournier, S. Consumers and their brands: Developing relationship theory in consumer research. J. Consum. Res. 1998, 24, 343-353. [CrossRef]

4. Hussey, M.; Duncombe, N. Projecting the right image: Using projective techniques to measure brand image. Qual. Market Res. Int. J. 1999, 2, 22-30. [CrossRef]

5. McDonagh, D.; Bruseberg, A.; Haslam, C. Visual product evaluation: Exploring users' emotional relationships with products. Appl. Ergon. 2002, 33, 231-240. [CrossRef]

6. Cian, L.; Cervai, S. The Multi-Sensory Sort (MuSeS): A new projective technique to investigate and improve the brand image. Qual. Market Res. Int. J. 2011, 14, 138-159. [CrossRef]

7. Greenwald, A.G.; Banaji, M.R. Implicit social cognition: Attitudes, self-esteem, and stereotypes. Psychol. Rev. 1995, 102, 4-27. [CrossRef] [PubMed]

8. Bruseberg, A.; McDonagh-Philp, D. New product development by eliciting user experience and aspirations. Int. J. Hum.-Comput. Stud. 2001, 55, 435-452. [CrossRef]

9. Knight, S. NLP at Work: Neuro Linguistic Programming, 3rd ed.; Nicholas Brealey Publishing: London, UK, 2009.

10. Donoghue, S. Projective techniques in consumer research. J. Fam. Ecol. Consum. Sci. 2000, 28, 47-53. [CrossRef]

11. Hofstede, A.; van Hoof, J.; Walenberg, N.; de Jong, M. Projective techniques for brand image research. Qual. Market Res. Int. J. 2007, 10, 300-309. [CrossRef]

12. Vidal, L.; Ares, G.; Giménez, A. Projective techniques to uncover consumer perception: Application of three methodologies to ready-to-eat salads. Food Qual. Preference 2013, 28, 1-7. [CrossRef]

13. Catterall, M.; Ibbotson, P. Using projective techniques in education research. Br. Educ. Res. J. 2000, 26, 245-256. [CrossRef]

14. Boddy, C. A look at the evidence for the usefulness, reliability and validity of projective techniques in market research. Int. J. Market Res. 2005, 47, 239-254.

15. Kinnear, T.C.; Taylor, J.R. Investigación de Mercados: Un Enfoque Aplicado, 1st ed.; McGraw-Hill: Mexico City, Mexico, 1993.

16. Guerrero, L.; Claret, A.; Verbeke, W.; Enderli, G.; Zakowska-Biemans, S.; Vanhonacker, F.; Hersleth, M. Perception of traditional food products in six European regions using free word association. Food Qual. Preference 2010, 21, 225-233. [CrossRef]

17. Caprara, G.V.; Barbaranelli, C.; Guido, G. Brand personality: How to make the metaphor fit? J. Econ. Psychol. 2001, 22, 377-395. [CrossRef]

18. Upadhyaya, M. Projective techniques for brand image dimensionality and using various techniques to investigate and improve the brand personality. Pol. J. Manag. Stud. 2012, 6, 89-100.

19. Aaker, J.L. Dimensions of Brand Personality. J. Mark. Res. 1997, 34, 347-356. [CrossRef]

20. Eisend, M.; Langer, A. The Impact of Brand Personality Dimensions on Brand Performance. In Proceedings of American Marketing Association Winter Educators' Conference, Chicago, IL, USA, 2007; pp. 168-169.

21. Van den Berge, E. Brand Personality along the Yardstick; SWOCC: Amsterdam, The Netherlands, 2002.

22. Azoulay, A.; Kapferer, J.N. Do brand personality scales really measure brand personality? J. Brand Manag. 2003, 11, 143-155. [CrossRef]

23. Austin, J.R.; Siguaw, J.A.; Mattila, A.S. A re-examination of the generalizability of the Aaker brand personality measurement framework. J. Strateg. Mark. 2003, 11, 77-92. [CrossRef]

24. George, S.L.; Charles, W.L. The measurement and dimensionality of brand associations. J. Prod. Brand Manag. 2000, 9, 350-370.

25. Geuens, M.; Weijters, B.; De Wulf, K. A new measure of brand personality. Int. J. Market Res. 2009, 26, 97-107. [CrossRef] 
26. Ferrandi, J.M.; Falcy, S.; Kreziack, D.; Valette-Florence, P. Aaker's brand personality scale: A replication and a double methodological validation in a French setting. In Proceedings of the 3rd International Research Seminar on Marketing Communications and Consumer Behavior, Aix-en-Provence, France, 1999.

27. Brislin, R.W. The wording and translation of research instruments. In Field Methods in Cross-Cultural Research; Lonner, W.J.E., Berry, J.W.E., Eds.; Cross-Cultural Research and Methodology Series; Sage Publications, Inc.: Thousand Oaks, CA, USA, 1986; Volume 8, p. 368.

28. Costa, F.P.B.S.; Borges, L.P.; Peréz, C. Os Sentidos da África nas Expressões da Marca Amarula. Pensam. Real. 2010, 25, 55-73. article distributed under the terms and conditions of the Creative Commons Attribution (CC BY) license (http://creativecommons.org/licenses/by/4.0/). 